\title{
THE PATHOLOGISATION OF SEXUAL DIVERSITY - A CRITICAL SCRUTINY OF THE DSM
}

Rita Alcaire

University of Coimbra, Portugal

\begin{abstract}
The Diagnostic and Statistical Manual of Mental Disorders (DSM) is the standard reference for the classification of mental disorders. This article draws on contributions from different areas of expertise to discuss three classifications concerning sexual orientations and identities created within the DSM throughout decades.

The aim of this paper is two-fold: 1) it will focus on the creation of psychiatric diagnoses for sexual practices, orientations and identities and 2) it will describe the resistance on the part of different groups whose behaviour is described within those terms. Three examples will be examined: homosexuality as a mental illness, trans* identity as 'gender dysphoria' and asexuality as 'hypoactive sexual desire disorder'.

Keywords: sexual diversity, DSM, pathologisation, human rights, activism, 'reflexive project'.

\section{Résumé}

La pathologisation de la diversité sexuelle - l'examen critique de la DSM

Le Manuel Diagnostique et Statistique des Troubles Mentaux (DSM) est la norme de référence pour la classification des troubles mentaux. Cet article s'appuie sur les contributions de différents domaines d'expertise pour discuter trois classifications concernant les orientations sexuelles et les identités crées dans le DSM tout au long des décennies. Le but de cet article est double: 1) il se concentrera sur la création de diagnostics psychiatriques pour les pratiques, les orientations et les identités sexuelles et 2) il décrira la résistance de la part des différents groupes dont le comportement est décrit dans ces termes. Trois exemples seront examinés: l'homosexualité comme maladie mentale, trans*identité en tant que 'dysphorie du genre' et l'asexualité comme 'trouble du désir sexuel hypoactif'.
\end{abstract}

Mots-clés: diversité sexuelle, DSM, pathologisation, droits humains, activisme, 'projet réflexif'.

\section{Resumo}

A patologização da diversidade sexual - uma análise crítica do DSM

O Manual Diagnóstico e Estatístico de Transtornos Mentais (DSM) é o padrão de referência para a classificação dos transtornos mentais. Este artigo baseia-se em contribuições de diferentes áreas do conhecimento para discutir três classificações relativas a orientações e identidades sexuais criadas pelo DSM ao longo de décadas.

O objetivo deste artigo é duplo: 1) incide sobre a criação de diagnósticos psiquiátricos para práticas, orientações e identidades sexuais e 2) descreve a resistência por parte de diferentes grupos cujo comportamento é descrito dentro desses termos. Três exemplos serão examinados: a homossexualidade como uma doença mental, a identidade trans* como 'disforia de género' e assexualidade como 'distúrbio de desejo sexual hipoativo'.

Palavras-chave: diversidade sexual, DSM, patologização, direitos humanos, ativismo, 'projecto reflexivo'. 


\title{
Introduction
}

\begin{abstract}
What is normal sexuality [or normal gender]?
What is the role of sexuality [or the role of gender] in human existence? Do the brute requirements of species' survival compel an answer to the question of whether homosexuality [or whether gender variance] is a disorder? How should social values influence psychiatry and help to define the concept of mental illness? What is the appropriate scope of a nosology of psychiatric disorders? How should conflicts over such issues be resolved? How should the opposing principles of democracy and authority be brought to bear in such matters?
\end{abstract}

(Bayer, 1987: 4)

DSM-5, the latest revised edition of the Diagnostic Statistical Manual of Mental Disorders was published by the American Psychiatric Association in May 2013. It is described as the "most comprehensive, current, and critical resource for clinical practice available to today's mental health clinicians and researchers of all orientations» (American Psychiatric Association, 2013).

Since its first edition in 1952, the DSM has been widely considered and often called the 'psychiatric bible' for it provides criteria for the classification and diagnostic of mental disorders that are used transnationally by mental health practitioners of different professional areas.

The mental health disorders section of the International Statistical Classification of Diseases and Related Health Problems (ICD) is another guide commonly used, especially outside the United States. It shares common grounds and is consistent with DSM in terms of diagnostic codes. But as far as mental health diagnoses are concerned, DSM continues to be the biggest reference worldwide as a basis of diagnostic practices, as well as for clinical care, research and training.

Although the manual is widely used in various contexts as the most legitimate tool for the purposes just mentioned, it has also been the subject of stern criticism (Garber, 2007; Frances, 2009; Davy, 2013), as many researchers, scholars and practitioners point out several conceptual flaws. Some even question its reason for existence.

The process of revision of the DSM leading to its fifth edition, which represents the first revision in the Internet era, was the subject of great scrutiny and media attention. Media interest in the DSM process had primarily focused on possible conflicts of interests of psychiatrists with financial ties to the pharmaceutical industry (Garber, 2007). Soon that interest shifted to the Lesbian, Gay, Bisexual and Transgender (LGBT) community, especially because of the stigma of existing diagnoses such as 'gender identity disorder' (to be addressed in the next section), and the social impact of the new proposed disorders such as 'hypersexuality'. 
Amongst the broad collection of mental disorders that the DSM can be used for, it is used to diagnose sexual behaviours, practices and identities in terms of normal/abnormal, healthy/unhealthy, with severe social, political and psychological consequences for individuals and groups already in a vulnerable position.

In this article I intend to bring forward a brief overview of several disciplinary perspectives to address the DSM sexual classifications. These, in their turn, draw on a whole set of discourses - legal, religious, psychiatric, medical which categorise sexual behaviour in terms of normality.

By way of example, I am going to discuss three case studies of the contested sexual classifications - both by individuals who fall under them and by some in the medical community - homosexuality as a 'mental illness'; asexuality as a 'hypoactive sexual desire disorder' and trans* identity as a 'gender dysphoria'.

\section{Sexual classifications and the DSM}

The three cases that I want to discuss in this paper refer to different editions of the DSM, each of which emerged in distinct socio-political contexts. Let us see how DSM-5 is introduced on the American Psychiatric Association site:

This new edition of Diagnostic and Statistical Manual of Mental Disorders (DSM$-5 \circledR)$, used by clinicians and researchers to diagnose and classify mental disorders, is the product of more than 10 years of effort by hundreds of international experts in all aspects of mental health. Their dedication and hard work have yielded an authoritative volume that defines and classifies mental disorders in order to improve diagnoses, treatment, and research.

I have chosen to open this section with this description because it announces both the purpose of all the previous editions of DSM and the intentions of APA for creating such a compendium. First of all, that it is a necessary (and unique) tool for the classification of all mental maladies and that its use is transversal to a broad array of mental health professionals and practitioners in different countries. The emphasis is put on expert knowledge and scientific credibility. It is also noticed that the data that it contains has been scientifically validated by the best experts (from several countries) in areas of expertise that are considered the most relevant, such as medicine, psychiatry, psychology, sexology, etc. The process of making the DSM was long and arduous, for the publication only comes after a decade of debates, verifications and consultations.

The result, as stated by APA, is «an authoritative volume that defines» what is considered normal or not, what is pathological or not, what fits the standards and what is left aside, anchored in the notion of 'authoritative', that immediately sends a message to the reader that it is an expert opinion or sends us to the realm of law. The truth is that in some jurisdictions, the DSM can act as an agent of law (Davy, 2013). 
The description continues as follows:

The criteria are concise and explicit, intended to facilitate an objective assessment of symptom presentations in a variety of clinical settings - inpatient, outpatient, partial hospital, consultation-liaison, clinical, private practice, and primary care. New features and enhancements make DSM-5® easier to use.

Whereas the first excerpt stresses the validity of the manual, the second one invokes notions of transparency, trustworthiness and immediacy. Just like a dictionary or a grammar, the DSM determines the meaning of the (sum of the) symptoms by making it correspond (univocally) to an illness, not considering different sets of personal experiences and, in some respects, replacing them with some kind of 'story'.

The social danger of DSM is that it becomes a good example of a biopolitical power tool, since it formulates the notion of norm regarding sexual behaviour, which has a devastating impact on people's lives and experiences. If someone's behaviour is considered to fit a specific pathological category, subsequent treatment (medication, psychotherapy, etc.) is assigned to them linked with a particular non-normative identity. By producing and operating ontological categories, DSM helps establish sexual orientation in a way that is historically and culturally homogenous and fixed. Michel Foucault (1994) pointed out that systems of categorisation do not just arrange content, but naturalise a certain mediated version of the world, and simultaneously render anything else more or less unthinkable.

DSM not only determines how mental disorders are defined and diagnosed, it has an impact on the ways in which people see themselves and others. While diagnostic terms facilitate clinical care and access for those who want it, these terms can also have a stigmatising effect. What this does is reinforce the idea of a universal (binary and normative) humanity and easily creates 'us vs. the others' that marginalises minority groups.

In the History of Sexuality: An Introduction (1990), Michel Foucault discusses the power networks and how authority figures (i.e. priests, doctors and adult caregivers) produce and disseminate messages that encourage heteronormativity. As a result, people who are subject to this kind of judgement may absorb those messages without questioning the assumptions that sustain and underlie them.

Many authority figures contribute to the discipline of bodies through the discourses that accommodate heteronormative ideologies. Health professionals in particular have the power to create 'scientific' and 'true' discourses about sexuality through physical and psychiatric evaluations and other medical procedures. Through these procedures, that can also be considered medical performances, health professionals, especially doctors, verify and ascertain normative and non-normative sexualities.

In Foucault's words, the medical community, and by extension the family, «questions, monitors, watches, spies, searches out, palpates, brings to light sexual 
practices that do not reinforce procreative ideologies» (1990: 45) and become the primary enforcers of the heteronormative. Society continues to be a sexual regime (with a script of what sexuality is supposed to be) and within this power network, sexuality becomes «a domain susceptible to pathological processes, and hence one calling for the therapeutic or normalizing interventions» (Foucault, 1990: 68). Narratives of the medical establishment deploy messages that encourage individuals to assume heterosexual identities instead of considering queer ones, because these networks of power ignore and reject queer narratives and emphasize the heteronormative, monogamous, coital reproductive model.

A number of questions need to be raised concerning these issues. They are reminiscent of Judith Butler's analysis of the narratives of the body (Butler, 1993), her discussion on vulnerability (regarding gender issues, but that can be used here) and precarious lives (which lives are worth living) (Butler, 2004). Echoing Foucault's ideas about power, Butler also states that this regulation of the process of humanisation (who is human, who is normal, whose life is worth living) also generates a particular susceptibility or vulnerability to different types of violence, particularly those individuals who do not (in part or in whole) satisfy the criteria of regulation (Butler, 1993; Butler, 2004).

Discursively, DSM also states that there are people that are especially vulnerable - a vulnerability that is considered defining and, in some cases, unchangeable - and so they (the others) need paternalistic protection from the medical community and the state healthcare system. DSM makes their authority legitimate by providing the state structures with the tool of separation of certain groups of people from society. It establishes, through discourse and political strategies, who are the vulnerable populations, and the lives that make sense in society.

\section{The diagnoses}

The issue of removal or re-framing of certain DSM sexual classifications homosexuality, asexuality and trans* identity - is quite complex and profound, and involves opposing forces. The opposition is situated not only between people surrounding and related to the process of DSM production such as activists and psychiatrists -, but also within the medical community and internal to the gay and lesbian, ace and trans* movements. In each case, uncertainty arises around the question of what exactly induced the change. Any attempt to draw linear accounts of any of these cases, misunderstands the multiplicity of powers at practice at the same time and the social, moral and political frameworks working backstage.

For the purposes of this article, I will briefly address the key moments in each fight for change, trying to do justice to historical and contemporary struggles around them; debate the questions of power that psychiatric diagnoses sus- 
tain over the gendered and sexual lives and bodies of many people and the potential impact of the manual's criteria for pathological, paraphilic and 'normal' sexualities, sexual orientations, gender identities and psychiatric practice.

\subsection{Homosexuality as a 'mental illness'}

Let us first consider the case of homosexuality, which was labelled a psychiatric illness in the nineteenth century and remained so until the 1970s. Although gay and lesbians today are still struggling for equal rights (marriage equality, coparenting and the adoption of children), no change seems to have been more drastic for the status of homosexuality than its removal from the classification as a mental illness.

In Homosexuality and American Psychiatry (1987), Ronald Bayer argues that this decision was the product of years of political pressure applied by gay activists. The general climate of radical dissatisfaction and pro-reform movements created the possibility for activists, alongside key political figures, religious organizations and civil rights leaders, to call on medical organisations and governments to adopt new social policies. Those movements stem from the Stonewall riots that occurred in June 1969, in Greenwich Village (New York), and fuelled gay activists to take action in different contexts and challenge the social and cultural status. For that reason, a group of activists disrupted the 1970 APA meeting in San Francisco, to contest the scientific credibility of homosexuality's 'mental illness' status, at the time perpetuated by what they considered to be unproven psychoanalytic assumptions as well as moral undertones.

This process of confronting (un)scientific ideas and values lead by activists allowed for the coming forward not only of psychiatrists that agreed with the revision of the DSM, but also contributed for the 'coming out' of gay psychiatrists, which strengthened the civil movements and their action inside the APA.

The following years (1971 and 1972) the APA meetings featured gay activists explaining to the practitioners' audience how the stigma caused by a mental disorder diagnosis had affected their lives. At APA's 1972 meeting, activists were joined by a psychiatrist John Fryer, who appeared as 'Dr. H Anonymous', wearing a disguise and using a voice-altering microphone, who told the audience how difficult and painful it was to live as a closeted gay psychiatrist (Bayer, 1987).

Judd Marmor, one of the first psychiatrists invited by the activists to join the 1972 panel about homosexuality, defended that the fundamental questions raised by the nosology of homosexuality, as stated by the DSM, were not medical or even of semantics, but had moral and social judgments at its basis. During the debate before the Nomenclature Committee, Marmor stressed: «It is our task as psychiatrists to be healers of the distressed, not watchdogs of our social mores.» (quoted in Herman, 1995: 101). 
These movements insisted that the American Psychiatric Association and the religious and professional groups addressed their prejudices, so the APA embarked upon an internal examination whether homosexuality should be considered a psychiatric disorder: the APA's Nomenclature Committee delegated a subcommittee to interview proponents of normalising and/or pathologising views which in the due course produced a thorough review of the psychiatrist, psychoanalyst, and sexologist literature on the subject.

The most common arguments used by psychiatrists who supported the removal of homosexuality from the list of mental illnesses were 1) the lack of scientific evidence for the understanding of homosexuality as a 'developmental disorder', supported by empirical studies - nonclinical samples concluded that there were no differences in psychological functioning among homosexuals and heterosexuals (Hooker, 1957; Bell and Weinberg, 1978); 2) the effect that the classifying homosexuality as a psychiatric entity would have on the individual, creating the grounds for social discrimination and violation of human rights. As a result, it was argued that homosexuality should be seen as a variant of the common and normal behaviour, as the data collected and published by Alfred Kinsey $(1948,1953)$ had already demonstrated.

After the revision of the specialist literature on the subject and the approval by other APA committees and deliberative bodies, APA's Board voted unanimously to remove homosexuality from the DSM on the $15^{\text {th }}$ of December 1973 and subsequently released a statement rejecting legal discrimination on the basis of sexual orientation. The resolution, stated that «the [APA] deplores all public and private discrimination against homosexuals in such areas as employment, housing, public accommodation, and licensing.» (Bayer, 1987: 136). Within two years, other major mental health professional organisations, namely the American Psychological Association, the National Association of Social Workers, and the Association for Advancement of Behavior Therapy endorsed the decision.

Both scientific literature and fieldwork have revealed that many psychotherapists continue to discriminate clients (Goldfried, 2001; Goldfried and Pachankis, 2007). This discrimination can happen in different ways, be it less visible, subtle or declared, for example by taking for granted the normative heterosexual orientation of their clients or prescribing sexual orientation conversion therapies.

In Portugal, research has shown that, generally, psychologists have no specific skills or knowledge regarding a positive intervention that is sensitive to the diversity of their clients. The research Discursos sobre a homossexualidade no contexto clínico: a homossexualidade dos dois lados do espelho (Discourses on homosexuality in the clinical setting: homosexuality on both sides of the mirror), by Gabriela Moita (2001) points to prejudiced behaviour by Portuguese mental health professionals when it comes to gay and lesbian clients, a behaviour that reflects in the ways they approach questions and doubts raised by them. The study examined different discussion groups consisting either of clinicians (psychologists and psychiatrists) or gay and lesbians who underwent therapeutic monitoring processes (for 
various reasons, not necessarily linked to homosexuality). The homophobia and heterosexism levels detected reveal, amongst other things, that in the Portuguese context, some clinicians understand homosexuality as a pathology or a deficiency and that there is clinical complicity with unquestioned models of training, which perpetuates, or even enlarges, social discrimination that gay and lesbians suffer.

\subsection{Asexuality: a desire disorder}

Asexuality is defined broadly as 'lack of sexual attraction' (AVEN, 2014). In psychiatry, the lack of sexual attraction has traditionally been approached as a medical condition - a psychological or physiological disorder. This is due, in large part, to the historical assumption that sexual desire is universal.

In little more than a decade (since the 2000s), asexuality - as an identity, a sexual orientation and a movement - has gained visibility and the idea that lack of sexual attraction is a disorder has been severely contested. It happened mainly because people who identify themselves as asexuals have claimed the status of sexual orientation and of identity for their absence of attraction (Alcaire, 2014). Furthermore, it has been due to the proliferation of virtual communities in the United States, like The Asexual Visibility and Education Network (AVEN), the largest asexual virtual community in the world, and the work of asexual activists.

Today, asexual activists and researchers alike consider the medical community to be more accepting of asexuality. Yet a long resistance against the psychiatric diagnosis had led to it.

The leading figure was Anthony Bogaert, a psychologist who published an article entitled «Asexuality: Prevalence and Associated Factors in a National Probability Sample» (2004) in the renowned Journal of Sex Research. The paper suggested that over one percent of the general population was asexual and that they shared a number of common traits, such as height, weight, socio-economic status and degree of religiousness.

Due to the great interest in the media, the author decided to research even more deeply about asexuality and tries to understand different questions that had arisen in interviews. Two years later, Bogaert published a follow-up paper, «Toward a Conceptual Understanding of Asexuality» in the Review of General Psychology, in which he sought to better articulate and define asexuality. One of the most important contributions of the new article was the demystification of asexuality as a medical condition also known as Hypoactive Sexual Desire Disorder (HSDD), and its conceptualization as a sexual orientation in its own right. Bogaert highlighted that the medical diagnose had resulted in the erroneous labelling of asexuals as being either sexually repressed, «late bloomers» or «broken» - which had painful implications in their personal lives.

AVEN reported that HSDD had been a regular (mis)diagnose within the asexual community, with the prescription of psychotherapy and medication. For 
that reason, asexual activists like David Jay (the founder of AVEN) joined Anthony Bogaert in arguing that the connection of asexuality and HSDD stems from its broad and vague definition in the fourth edition of DSM in 1994. DSM-4 describes HSDD as a sexual dysfunction that caused "marked distress or interpersonal difficulties" due to a lack or absence of "sexual fantasies and desire for sexual activity". A task force, formed by AVEN members, was created in 2008 to work specifically on the revision of the DSM-4 definition, maintaining the HSDD category, but allowing an exception for asexuality.

Similarly to what happened in the case of homosexuality, members of the medical and scientific community played a central role in this debate. When the DSM campaign was first underway, there was a clash with physicians who claimed that asexuals advocated the rejection of sexuality. The major challenge faced by asexual activists consisted in redefining HSDD while still being careful not to invalidate individuals who really do suffer from sexual disorders.

In May 2013, with the fifth edition of DSM published, the asexual community celebrated what they call a small yet meaningful victory. The DSM-5 reclassified HSDD under the umbrella of Sexual Interest/Arousal Disorders. This new definition makes a distinction between a lifelong, generalized lack of sexual desire and other forms of the disorder, such as a temporary or a specific lack of desire.

\subsection{Trans* identity: from disorder to dysphoria}

In the most recent edition of the DSM, people whose gender at birth differs from the one they identify with is diagnosed as 'gender dysphoria'. This concept results from a revision of the DSM-4's criteria for gender identity disorder and is considered to better characterize the experiences of children, adolescents and adults within this category.

Similarly to homosexuality, the medical scrutiny of 'transgenderism' also began in the 19th century. Furthermore, arguments for removal of the 'trans diagnoses' included societal intolerance of difference, the human cost of diagnostic stigmatization, using the language of psychopathology to describe what some consider to be normal behaviours and feelings and, finally, inappropriately focusing psychiatric attention on individual diversity rather than opposing the social forces that oppress sexual and gender nonconformity (Drescher, 2010).

Many cultures routinely conflate homosexuality with transgender identities because they rely upon several beliefs that use conventional heterosexuality and cisgender identities as a frame of reference. Once regarded as synonymous, it is only relatively recently that sexual orientation (defined as an individual's erotic response tendency or sexual attractions) and gender identity (defined as one's sense of oneself as being male, female or other) have been regarded as separate categories. 
What is important to retain here, is that, just like in the previous examples, the trans* anti-pathologisation movement argues for a radical paradigmatic shift, that is not centred on the medical diagnosis, but has self-determination at its core (Davy, 2013).

This approach is gaining weight because of governments, such as the Argentinean, that has recently legislated one of the most progressive trans-recognition law in the world. The Argentina Gender Identity Law (TGEU, 2012) allows people to change their gender in official documents without receiving a psychiatric diagnosis or surgery. This law gives an individual the right to self-identify and if the person considers there is a need for medical intervention to transition (in any way he or she finds suitable), public and private providers are required to cover procedures.

Self-determination, according to some trans* advocates, is another way of making recognition claims for those wanting technological interventions to change gender beyond a psychiatric frame (Cuban Multidisciplinary Society for Sexuality Studies, 2010; TGEU, 2012). Transgender Europe situates self-determination within a human rights discourse. In this literature it emphasizes that every trans* person has a right to actualize their transition, as far as they wish it should go. (Davy, 2013: no page number)

The claims for self-determination challenge pathologisation of trans* identities, remove the necessity for psychiatric diagnoses ('gender identity disorder', 'gender dysphoria', 'gender incongruence') and allow for the acknowledgement of several trans* identities, moving beyond the dualist notion of 'trans'.

\section{Concluding remarks}

We're rejecting you as our owners. We possess ourselves and we speak for ourselves and we will take care of our own destinies Frank Kameny, president of the Mattachine Society of Washington Quoted in Bayer, 1987: 106

Several sexual identities and orientations were once labelled mental disorders by DSM, and therefore generally accepted in psychiatric and medical practice. The resistance and challenging to this understanding came either from within the medical community, from other disciplines or sexual activists. With this challenging of norms and values, bodies and lives were reclaimed.

The three cases analysed in this paper seem to follow a similar course, as the voices of researchers, practitioners and activists pointed the incorrectness of labelling sexual identities, orientations and gender variance as symptoms of a mental disorder and that perpetuating diagnoses in different revised editions of 
the DSM, with its social (allowing for human rights violations and discriminations) and political implications (lack of legal protection, for example), would further stigmatization and harm highly vulnerable individuals.

This reframing (ace and trans*) or abolition (homosexuality) of these sexual classifications is a direct result of the asexual and trans* communities' actions, and of the gay and lesbian rights movement. It illustrates how these movements seek to construct their own social narratives, refusing to accept what psychiatrists wanted to make of them. These groups of people reclaimed their identity to state that difference was not a disease, nonconformity was not a pathology and uniqueness was not an illness.

We can consider that, in these three case studies, there was an emergence of a 'reflexive project', borrowing the concept from Anthony Giddens. This means «a social phenomenon that can be appropriated and transformed through collective commitment» (1995: 9). Giddens explicitly points out gay and lesbian identities as examples of highly reflexive forms. But I wish to extend this idea to the asexual and trans communities and their struggles, considering that reflexivity, as I understand it, is deeply connected with self-consciousness, self-determination and empowered agency, and therefore, to the ability and the right to 'selfmaking'.

And in every one of these three examples, there was (especially in the United States, but also echoed around the world), the concern to reconceptualise and transform their public image. In that respect, Giddens draws our attention to the word 'gay' as a synonym of male homosexual. It not only centres power on the community that created it, but brings a more colourful, open idea of being homosexual, and agency to the ones using it. The same happened with asexuals and trans* individuals, by refusing the nomenclature created by doctors and strengthening their education and awareness actions.

The emphasis on each of these contesting processes was towards a human rights approach, amongst other things by stressing out the social meaning of these changes. These struggles were definitely an important step in the elimination of the pathologisation and discrimination pattern, not only in medical terms, but also, at a very slow pace, in terms of day-to-day living.

\section{References}

Alcaire, Rita (2014), «'It wasn't until Google that we found each other': The internet as a primary locus of mobilization for the asexual community», Paper presented for the module on «Scales and Practices of Human Rights: Legalization, mobilization and contestation», PhD in «Human Rights in Contemporary Societies», $1^{\text {st }}$ semester, $1^{\text {st }}$ curricular year.

American Psychiatric Association (2013), American Psychiatric Publishing, [online] available at http://www.appi.org/SearchCenter/Pages/SearchDetail.aspx?ItemId=2555\# [retrieved on 01/02/2014]. 
AVEN - The Asexuality Visibility and Education Network (2014) [online], available at www.asexuality.org [retrieved on 10/03/2014].

Bayer, Ronald (1987), Homosexuality and American Psychiatry: The Politics of Diagnosis, New Jersey, Princeton University.

Bell, Alan; Weinberg, Martin (1978), Homosexualities: A study of diversity among men and women, New York, Simon and Schuster.

Bogaert, Anthony (2004), «Asexuality: Its prevalence and associated factors in a national probability sample», The Journal of Sex Research 41, 279-287.

Bogaert, Anthony (2006), «Toward a conceptual understanding of asexuality», Review of General Psychology 10, 241-250.

Butler, Judith (1993), Bodies that Matter: on the discursive limits of 'sex', New York, Routledge.

Butler, Judith (2004), Precarious Lives: The Powers of mourning and violence, London, Verso.

Davy, Zowie (2013), Commentary on the construction of Gender Dysphoria at Classifying Sex: Debating the DSM-5, [online] available at http://eprints.lincoln.ac.uk/12624/3/Commentary $\% 20$ on $\% 20$ the $\% 20$ construction $\% 20$ of $\% 20$ Gender $\% 20$ Dysphoria $\% 20$ at $\% 20 \mathrm{Cl}$ assifying\%20Sex\%20Debating\%20DSM\%205.pdf [retrieved on 01/02/2014].

Drescher, Jack (2010), «Queer Diagnoses: Parallels and Contrasts in the History of Homosexuality, Gender Variance and the Diagnostic and Statistical Manual», Archives of Sexual Behavior, 9(2), 427-460.

Foucault, Michel (1994), The Order of Things: An archeology of the Human Sciences, New York, Vintage Books.

Foucault, Michel (1990), The History of Sexuality: An Introduction, New York, Vintage Books.

Frances, Allen (2009), A Warning Sign on the Road to DSM-V: Beware of Its Unintended Consequences, [online] available at http://www.psychiatrictimes.com/articles/ warning-sign-road-dsm-v-beware-its-unintended-consequences [retrieved on 01/08/2014].

Garber, Kent (2007), Who's behind the bible of mental illness: Critics say that touted efforts against conflicts fall short, [online] available at http://health.usnews.com/ health-news/articles/2007/12/20/whos-behind-the-bible-of-mental-illness [retrieved on 03/06/2014].

Giddens, Anthony (1995), Transformações da intimidade: Sexualidade, amor e erotismo nas sociedades modernas, Oeiras, Celta Editora.

Goldfried, Marvin (2001), «Integrating gay, lesbian, and bisexual issues into mainstream psychology», American Psychologist 56, 977-988.

Goldfried, Marvin; Pachankis, John (2007), «Commentary: Homosexuality - toward affirmative therapy», in J. Christopher Muran (Ed.), Dialogues on Difference: Studies of diversity in the therapeutic relationship, Washington, APA, 98-106.

Herman, Ellen (1995), Psychiatry, Psychology and Homosexuality, New York, Chelsea House.

Hooker, Evelyn (1957), «The adjustment of the male overt homosexual», Journal of Projective Techniques 21, 18-31.

Moita, Gabriela (2001), Discursos sobre a homossexualidade no contexto clínico: a homossexualidade dos dois lados do espelho, PhD Dissertation, Instituto de Ciências Biomédicas Abel Salazar da Universidade do Porto.

TGEU - Transgender Europe, The Argentina Gender Identity Law, [online] available at http://www.tgeu.org/Argentina Gender Identity Law [retrieved on 01/02/2014]. 
Rita Alcaire. Anthropologist. PhD candidate in Human Rights in Contemporary Societies and Master in Cultural Psychiatry. Her main research interests are identities, sexualities, personal narratives and 'popular culture' (film, television and music). Her academic and professional career has focused on a search for possible answers to various questions that have emerged around these subjects, with the use of video-documentaries as a privileged form to engage with them.

Centro de Estudos Sociais, Colégio de s. Jerónimo, Apartado 3087, 3000-995 Coimbra, Portugal

rita@rita-alcaire.com

Artigo recebido em 20 de outubro de 2014 e aceite para publicação em 5 de janeiro de 2015. 